\title{
Soğuk Savaş Sonrası Bosna-Hersek Bağımsızlık Süreci ve Aliya İzzetbegoviç ${ }^{1}$
}

\author{
Gül Tuba DAĞCI²
}

Adnan DAL ${ }^{3}$

\section{Özet}

Yugoslavya Federal Sistemi'nin bozulmaya yüz tutmuş yapısı içerisinde ayrılık sinyalleri veren devletler arasında yer alan Bosna-Hersek 'in bağımsızlık ilanı ve bu ilan karşısındaki Sırp tutumu, 2. Dünya Savaşı sonrası Avrupa'da en kapsamlı ve bir o kadar da yıkıcı bölgesel bir savaşın çıkmasına neden olmuştur. Savaş, iki kutuplu dünyadan galip çıkan ABD ve Soğuk Savaş sürecinde ekonomik ve kısmen de olsa siyasi birliktelik hedeflerine ulaşan $A B$ ülkelerinin kimlik oluşturma çabaları arasında bölgesel bir hegemonya mücadelesine, yenilenen Rusya ve Asya blokunun dâhil olmasıyla bölgesel olmaktan çıkıp küresel bir mücadele haline dönüşmüştür. Bosna-Hersek halkının hayatta kalma ve varlık mücadelesinin bu küresel hedeflerle karşılaşması, bağımsızlık mücadelesini karmaşık bir hâle sokmuştur. Böyle bir ortamda entelektüel, bilge kişiliğiyle savaşın strateji ve yöntemleri üzerinde ciddi etkiler yaratan Aliya İzzetbegoviç'in incelenmesi ve savaş sürecindeki rolü, çalışmamızın temel amacıdır.

Anahtar Kelimeler: Üçüncü Yol, Doğu-Bat1, Soğuk Savaş, Düalizm

\section{The Independence Process Of Bosnia-Herzegovina After Cold War And Alıja Izetbegovic}

\section{Abstract}

As a part of Federal Yugoslavia, which is demonstrating signals of separation in recent years, Bosnia-Herzegovina's declaration of independence and the response of Serbian against this, caused the most comprehensive and devastating war after World War II. The war against Bosnia-Herzegovina transformed to a

1 Bu çalışma Yalova Üniversitesi Sosyal Bilimler Enstitüsü’nce kabul edilen yüksek lisans tezinin bir özeti niteliğindedir.

2 Yrd. Doç. Dr., Yalova Üniversitesi Uluslararası İlişkiler Bölümü, dacituba@gmail.com

3 Arş.Gör., Yalova Üniversitesi Uluslararası İlişkiler Bölümü, adnan.dal@yalova.edu.tr 


\section{$108 \cdot$ YALOVA SOSYAL BILLIMLER DERGISI}

hegemony struggle between USA, the superior of bipolar international system and the European Union trying to construct an economical and political alliance, even partially, through European countries and got a global war by including Russia and Asian countries. Facing global struggle, Bosnia's people's survival and struggle of existence, got the independence effort more complicated. In such an environment, the main purpose of our paper is to examine the role of Alija Izetbegovic who formed serious impact on the strategies and methods of war through his intelectual character during war process.

Keywords: Third Way, East-West, Cold War, Dualism

\section{Giriş}

Uluslararası ilişkiler disiplininin ana sütunlarından birini oluşturan uluslararası politika, özü itibarıyla siyasi tarih araştırmalarından yoğun bir şekilde yararlanmaktadır. Bu anlamda siyasi tarih incelemeleri, disiplininin ana aktörlerinden olan devletlerin siyaset felsefesini incelemede bir ön araştırma görevi görür. Bu ön araştırma sayesinde uluslararası politika, tarihten motive olmuş, geleceğe iyimser bir bakış açısıyla yön vermeye çalışan siyasi liderlerce yürütülmeye çalışılmıştır. Uluslararası barış ve güvenliğin tesisi adına görev yapan bu liderler, tarihin karanlık odalarında yön bulmaya çalışan, yaşadıkları toplumun sosyo-kültürel şartlarıyla şekillenen ve bu şartlar çerçevesinde karar alma mekanizmalarını yürüten aktörler olmuştur. Buradan hareketle oluşturulan bu makale, Bosna-Hersek ve Aliya İzzetbegoviç üzerine tarihle uyumlu olmaya çalışan bir araştırmadan ibarettir. Araştırmada Aliya İzzetbegoviç’in içinde bulunduğu siyasi-toplumsal kültür, onun ortaya koyduğu siyaset felsefesi ve son olarak 20. yüzyıl İslam düşünürleri arasında onu farklı kılan özellikler yer almaktadır.

Bilindiği gibi Soğuk Savaş, uluslararası toplumu yaklaşık yarım yüzyıl boyunca etkileyen, zaman zaman dünyayı nükleer savaşın eşiğine getiren, ideolojik, siyasal bir kutuplaşmayı ifade etmiştir. II. Dünya Savaşı'nın en kârlı ve güçlü ülkelerinden olan ABD ve SSCB'nin oluşturduğu iki kutup ve bu kutuplar etrafında şekillenen ülkelerin oluşturduğu iki kutuplu sis-

YIL: 6 SAYI: 11 
tem, taraf ülkeleri klasik güç dengesi sisteminden çok daha fazla endişeye sevk etmiştir. Savaş sonrası yoğun bir şekilde silahlanmaya giden ABD ve SSCB, süreç içerisinde uluslararası toplumu korkutan bir silahlanma yarışına girmiştir. Bu yarış, zamanla iki kutuplu sistemin gevşemesine veya tam aksine gerilmesine neden olmuştur. 1970'li yıllar ile başlayan yumuşama havası ve bu dönemlerde üçüncü bir blok olma hedefinde olan ülkelerin oluşturduğu Bağlantısızlar Grubu, sistemin zaman içerisinde sorgulanmasına yol açmış, bu ülkeler kendi ulusal hedeflerine ulaşmak amacıyla sisteme muhalif bir siyaset yürütmeye çalışmıştır. 80'li yıllara doğru gelinirken öncelikle Doğu Avrupa ülkelerinin Sovyet bloğuna karş1 ayaklanma hareketleri, bu dönemin sonuna doğru SSCB'yi kimlik kriziyle baş başa bırakmıştır. Gorbaçov'un yenilenme amaçlı sistemi ayakta tutma çabaları başarısızlıkla sonuçlanmış, nitekim SSCB 1991'de dağılmıştır. SSCB'nin dağılması ABD-SSCB, kapitalizm-komünizm, NATO-Varşova Paktı mücadelelerinin ilki lehine sonuçlanmasını ifade etmiştir. ABD'nin bu mücadeleden galip çıkmasıyla beraber uluslararası sistemin niteliği tartışma konusu olmuştur. Özellikle küreselleşme olgusuyla beraber uluslararası toplumun yoğun bir etkileşim sürecine girmesi ve tekno-iletişimin artarak mesafe denen kavramı sorgulamaya başlaması, analistlerin sistem üzerinde yeni tanımlamalar yapmasını gerekli kılmıştır. İşte bu yeni tanımlamaların 1şı̆̆ında Aliya İzzetbegoviç ve onun ortaya koyduğu siyaset felsefesi sistemsel tartışmalara yeni bir boyut kazandırmıştır.

I. Dünya Savaşı sonrası kurulan Yugoslavya, II. Dünya Savaşı'nın başlangıç yıllarında Alman işgaline uğramış, savaş sonrası ülke tekrar bağımsızlığını kazanmıştır. Soğuk Savaş döneminde SSCB ile anlaşmazlık yaşayan Tito liderliğindeki Yugoslavya, ülkenin istikrar ve bütünlügüüü sağlamak adına ülke içerisindeki Müslüman halka zamanla kurucu halk statüsünü vermiştir. Ancak Tito sonrası dönem için istikrardan bahsetmek mümkün olmamıştır. 1980'li yılların sonuna doğru gelinirken Slovenya ve Hırvatistan'ın ayrılık sinyallerinin Avrupa ülkelerince olumlu görülmesi sonucu federal devletin baskın etnik gruplarından olan Sırpların bu ülkelere saldırısı başlamış; ancak iki ülke de Avrupa ülkelerinin bir kısmının, özellikle Almanya'nın desteğiyle bağımsızlığını kazanmıştır. Bu ülkelerin bağımsızlığı karşısında Sırp nüfuzu altında yaşamak istemeyen ve bağım- 


\section{$110 \cdot$ YALOVA SOSYAL BILLIMLER DERGISI}

sızlıktan yana tercih koyan Bosna-Hersek de Sirp saldırısına maruz kalmış; ancak bu ülke, Slovenya ve Hırvatistan'ın aldığı destek gibi Avrupa ülkelerinden destek görememiş, dolayısıyla Avrupa'nın ortasında yüzyılın en kanlı çatışmalarına sahne olmuştur.

Müslümanların yoğun olarak yaşadığı yerlerden biri olan Bosna-Hersek'de yaşayan Aliya İzzetbegoviç, esasında 20.yy siyasi olaylarının dönüm noktalarını bu bölgede yaşamıştır. I.Dünya Savaşı kalıntıları, II. Dünya Savaşı, Soğuk Savaş, küreselleşme dalgası, kapitalizm-komünizm mücadelesi, Almanya'nın siyasi birliğini tekrar sağlaması, Avrupa Birliği ve Birleşmiş Milletler' in kurulması gibi uluslararası sistemi domine eden, bir anlamda çok yönlü bir ilişkiler ağının oluşmasını sağlayan olaylara Aliya İzzetbegoviç canlı bir tanık olmuştur. İzzetbegoviç bu yıllar içerisinde krallık, faşizm, komünizm, demokrasi gibi farklı siyasal yapılanmaları da tecrübe eden ender liderlerden biri olmuştur. Onun yaşadığ 1 bu tecrübeleri kendi düşünce tarzıyla yoğurarak eserlerinde bir beyin firtınasına tabi tutması, onun 20. yüzyıldaki liderler arasından sıyrılıp farklı bir gözle değerlendirilmesini sağlamıştır. Felsefi birikimini sahip olduğu İslam inancıyla şekillendirmeye çalışan Aliya İzzetbegoviç, diğer liderlerden farklı olarak yazdıklarını siyaseten uygulamış bir liderdir. Ayrıca İslam coğrafyasında yaşanan çatışmaları çözüme kavuşturmak amacıyla bizlere sunduğu '’ $\dot{I}_{s}$ lami Düzen-İslami Yeniden Doğuş” tezi de onun araştırılmaya değer bir lider, düşünür olduğunu göstermektedir.

Bu araştırma Aliya İzzetbegoviç’in kişisel hayat mücadelesini sunmak gibi bir araştırmadan ziyade, onun bir düşünür olarak eserlerinde ortaya koyduğu siyaset felsefesinin uluslararası sistemin işlerliğine yaptığı katk1yı incelemek amacıyla oluşturulmuştur. Bunun yanı sıra düşünürün uluslararası ilişkiler teorilerine yaptığı açılım da bu işlerlik açısından dikkate alınmıştır. İnceleme ayrıca Aliya İzzetbegoviç'in eserleriyle ortaya koyduğu İslami düşünce tarzını da içermektedir; zira onun sadece bir yanını ele almak, nesnellikten uzak bir araştırma yapmak demektir. Dolayısıyla çalışma çok yönlü bir karakter analizini içeren sosyolojik bir inceleme şeklinde de değerlendirilebilir. Üç bölümden oluşan söz konusu bu araştırmanın 1. bölümünde Aliya İzzetbegoviç'in içinde bulunduğu siyasal-kültürel ortama değinilmiş, bu kapsamda Yugoslavya ve Bosna-Hersek ile ilgili 
bir siyasi tarih incelemesine yer verilmiştir. Konunun ana-gövde kısmını oluşturan 2. ve 3. bölümlerinde ise öncelikle Aliya İzzetbegoviç’in siyaset felsefesine, uluslararası ilişkiler disiplinine yönelik teorik açılımına ve son olarak "İslami Yeniden Doğuş" tezine yer verilmiştir.

\section{Metodoloji}

Uluslararası toplumu yaklaşık yarım yüzyıl etkileyen Soğuk Savaş’ın bitişine doğru çözülme sürecine giren Yugoslavya içerisinde, Bosna-Hersek'de bir hayatta kalma ve siyaset mücadelesi veren Aliya İzzetbegoviç'i ele aldığımız bu araştırmada öncelikle birincil kaynaklara ulaşılmaya çalışılmış, bu maksatla Aliya İzzetbegoviç'in kendi eserleri tek tek incelenerek araştırma sürecine dâhil edilmiştir. Ayrıca söz konusu düşünürü her yönüyle tanımak için içinde bulunduğu siyasal, sosyal ortam ve koşullar da göz önünde bulundurularak genel anlamda bölgenin siyasi tarihine 1ş1k tutacak kaynaklardan da yararlanılmıştır. Ek olarak süreç içerisinde gelişen olayları konu edinen dergi, makale, gazete ve internet ortamındaki her türlü bilgiden yararlanıldıktan sonra araştırma nihayete erdirilmiştir.

\section{Bosna-Hersek Siyasi Tarihi}

Bosna-Hersek, Avrupa'da etnik çeşitliliğin en yoğun yaşandığı yerlerden biridir ve Balkanlar denilen, etnik açıdan karmaşık bir bölgede yer almaktadır. Bu özelliğinden dolayı tarih içerisinde kanlı birçok çatışmaya sahne olmuş ve ekonomik ve siyasi istikrarın nadiren sağlandığı bir ülke haline gelmiştir. 20. yy.daki iki dünya savaşının da en kanlı çatışmalarının yaşandığı yerlerin başında gelen bölgenin bu yapısı, onun gelecekteki kaderini de belirlemiştir. Dolayısıyla analistler tarafından bu bölge bazen içerisinde "yontulmamış aşırılıkları" barındıran bir bölge (Judt, 2009: 796), bazen de Soğuk Savaş sonrası AB, ABD, NATO, Rusya gibi yeni güçlerin "'sınanma alanı” olarak ifade edilmiştir. (Davutoğlu, 2009: 291)

Uluslararası toplumu I.Dünya Savaşı'na sürükleyen Avusturya-Macaristan veliahdının bu bölgede öldürülmesi sonucu ortaya çıkan çatışmaların ardından 1918'de kurulan Sırp-Hırvat-Sloven krallığı 1929 yılında 


\section{$112 \cdot$ YALOVA SOSYAL BiLIMLER DERGISI}

Yugoslavya adını almış ve ülkeyi bu üç ana etnik unsur temsil etmeye başlamıştır. Esasında ülkenin etnik yapısı çok daha karmaşıktır. Nitekim Yugoslavya altı cumhuriyet, beş ulus, dört dil, üç din ve iki alfabenin barındığı bir ülke olarak tarihi kayıtlara geçmiştir. Ülkede ayrıca Türkler, Almanlar, Macarlar, Romenler, Vlaklar, Arnavutlar ve İtalyanlar da yaşamıştır. (Roberts, 2013: 1106) Bu karmaşık etnik yapı, ülke içerisinde istikrar ve barışın sağlanmasını zorlaştırmış; II. Dünya Savaşı'nda bölge Alman işgaline uğramış, 1945 yılında savaşın bitimiyle beraber ülke tarihinde ve iki kutuplu uluslararası sistemde belirgin bir etkiye sahip olan Tito göreve gelmiştir. (Berghorn, 2013: 464)

Tito göreve başladığında ülkenin siyasi-askeri anlamda egemen etnik unsuru Sırplar idi. Ancak Tito'nun istikrar sağlama amaçlı girişimleri zamanla ülkede bir "Yugoslav" kimliğinin oluşmasını sağlamış, bu sayede ülkenin Sırp hegemonyası altına girmesi engellenmiştir. (Armaoğlu, 2012: 1103) Tito, ayrıca yönetim kademelerinde etnik uyumun sağlanması adına çeşitli girişimlerde bulunmuş, bu sayede etnik unsurların siyasete aktif katılımını teşvik etmiştir. Bunun yanı sıra iki kutuplu uluslararası sistemin zaaflarını gözlemleyen Tito, süreç içerisinde bu sistemin dışında bir alternatif olmaya çalışan 'Bağlantısızlar" grubunun da en etkili liderlerinden olmuştur. (Sander, 2004: 576)

1980’de Tito'nun ölümüyle beraber bölgede bütün istikrar sağlama girişimleri sekteye uğramıştır. Tito'nun törpülemeye çalıştığı etnik milliyetçilik tekrar gün yüzüne çıkmış, ülke yoğun çatışmalara sahne olmuştur. (Alkan, 2013: 33) Ekonomik, siyasi, kültürel etkenlerden kaynaklanan bu çatışmalar 1980'li yılların sonuna doğru ülkenin parçalanmasına neden olmuştur. Sistemde ayrılık sinyalleri veren ülkelerden biri Slovenya olmuştur. 1986'da yayımlanan 'Sırp Memorandumu"nun Sırp milliyetçiliğine teorik çerçeve sunması ve Sırp lider Miloseviç’in 1989'da Kosova ve Voyvodina'nın özerkliklerini kaldırma girişimi, federal sistemde yer alan Slovenya'nın bağımsızlık kararı almasına yol açmıştır. Federal sistemin gelir düzeyi en yüksek ve etnik bakımdan en homojen bölgesi olan Slovenya'nın bağımsızlık ilanının Avrupa ülkelerince kabul edilmesinin ardından Hırvatistan da aynı yönteme başvurmuştur. İki ülkeye de yapılan Sırp saldırısı hem askeri açıdan hem de siyasi açıdan başarısız olmuştur. 
Ancak aynı şeyi Bosna-Hersek için söylemek mümkün olmamıştır. Hırvat ve Slovenlerin sistemden ayrılması durumunda Boşnaklar da Sırp egemenliğine dayalı bir federal sistemde kalmayacaklarını ilan edip bağımsızlık kararı almış; ancak bu ülke Sırplarca işgal edilmiş ve soykırıma varan ciddi saldırılara maruz kalmıştır. (Erdoğan, 2004: 22 ve Judt, 2009: 803)

Aliya İzzetbegoviç'in '’Yugoslav totaliterliğinin en uğursuz çekirde$\breve{g} i$ ”, şeklinde ifade ettiği Bosna-Hersek 1990'lı yılların başında yapılan ilk çok partili seçimde Demokratik Eylem Partisi (SDA), Sırp Demokratik Partisi (SDS) ve Hirvatistan Demokratik Birliği (HDZ) gibi partilerce yönetilmeye başlanmıştır. Boşnaklar, Sırplar ve Hırvatları temsil eden bu partilerin hükümet içerisindeki oy dağılımı Boşnaklar lehine olmuştur. (İzzetbegoviç, 2003: 76) Aliya İzzetbegoviç liderliğindeki SDA, Slovenya ve Hirvatistan'ın Yugoslavya'dan ayrılmasıyla 1992 yılında yapılan referandumla bağımsızlık kararı almış, bu tarihten sonra Boşnaklara yönelik Sırp saldırısı başlamıştır. Yaklaşık üç buçuk yıl süren savaşın ilk etapları Sırplar lehine olurken, son dönemlerine doğru Boşnakların önemli bir başarı sağladıklarına tanık olunmuştur. Neticede Sırp milliyetçiliğinin körüklediği ve Srebrenitzsa gibi soykırımların yaşandığı bölge, II. Dünya Savaşı'ndan beri Avrupa'da en kanlı olaylara sahne olan yer olarak tarihe geçmiştir.

Rotasyon usulüyle belirlenen başkanlığın 1991 yılında Hırvatları temsilen Stipe Mesiç'e devredilmesi gerektiği halde Sırpların bunu sabote etmesi Hırvat-Sırp çatışmasına da sebep olmuştur. Sırpların, Krajina bölgesine yönelik nüfuz arttırma girişimlerini bastırmaya çalışan Hırvatlar bu anlamda topyekün bir savunmaya geçmişlerdir. (Erdoğan, 2004: 25) Yugoslav Federal Sistemi'nde ciddi bir kriz olarak görülen bu olay sonrası ilerleyen süreçte Sırplara karşı bir Hırvat-Boşnak ittifakı da doğmuştur. Esasında her etnik grubun da ayrı ayrı hedefleri bulunmaktaydı. Hırvatlar, Bosna-Hersek içerisindeki Hırvatları anavatana yakınlaştırmak ve Krajina üzerinden Sırplara üstünlük sağlamak gibi taktiksel bir çaba sarf ederken, Sırplar ise federal sistemin kuruluş yıllarından beri sahip oldukları bürokratik ve askeri gücü diğer etnik gruplar üzerinde bir baskı unsuru olarak kullanmak ve nihai aşamada Yugoslavya'nın yeniden toparlanmış yapısında kilit rolü oynamak şeklinde bir strateji belirlemiştir. Boşnaklara 


\section{$114 \cdot$ YALOVA SOSYAL BILLIMLER DERGISI}

gelinecek olursa, esasında Boşnakların tek hedefi, Aliya İzzetbegoviç’in kişisel görüşleri de değerlendirilecek olursa, bağımsızlıkları kabul edilen ve sistemden ayrilan ülkelerin sahip olduğu haklara sahip olmak, bu sayede Sırp egemenliği altında yaşamaktan sıyrılmak şeklinde belirlenebilir. (İzzetbegoviç, 2003: 64 ve Kenar, 2013: 185)

Boşnakların ilan ettikleri bağımsızlık kararının Avrupa Topluluğu (AT) tarafından kabul edilmesiyle beraber Sırpların Boşnaklara karşı başlattığı saldırılar tahmin edilemeyecek derecede tehlikeli olayların yaşanmasına neden olmuştur. Saldırı karşısında Avrupa ülkelerince Boşnaklara verilen yardım sözü havada kalmış, Birleşmiş Milletler (BM) tarafından Yugoslavya'nın tümüne uygulanan silah ambargosu da Sırpların elini daha da güçlendirmiştir. Federal sistemin askeri ve bürokratik gücünün büyük bölümünü elinde tutan Sirplar, kontrolleri altındaki askeri mühimmatla Boşnaklara soykırım uygulama girişimlerini başlatmış, Srebrenitzsa'da 8000'i aşkıı Boşnak soykırımla karşı karşıya kalmıştır. Bütün bu saldırılar karşısında AT, BM, ABD, NATO gibi Batılı güçler tepkisiz kalmaktan öteye gidememiştir. Hatta AT bloğunda yer alan İngiltere ve Fransa uzun süre NATO'nun Sırplara yapılması planlanan saldırılarını engelleme girişimlerinde bulunmuştur. AT içerisinde Almanya-Fransız ikiliğine dönüşen bu olay, BM'nin saldırıları önleme girişimleri çerçevesinde aldığı kararların da havada kalmasıyla sonuçlanmıştır. Avrupa barışını da tehlikeye sokan bu çatışma, neticede NATO çevresinde kümelenen Avrupa güçlerinin ciddi bir adım atmasını gerektirmiştir. ABD olmaksızın Avrupa güvenliğinin sağlanamayacağını anlayan Avrupa ülkeleri, NATO'yu bölgeye davet etmiş, ABD de bu rolü üstlenerek bölgesel çaptaki görevini küresel liderliğini pekiştirmek adına başarılı bir şekilde yerine getirmiştir.

Soğuk Savaş döneminin en önemli olaylarından biri olan bu kriz, NATO, BM, AT gibi fraksiyonların meşruiyet krizine girmesine sebep olmuştur. Sırp saldırılarının başladığı ilk dönemlerde ABD çatışmaları Avrupa'nın iç sorunu çerçevesinde değerlendirmiş, dolayısıyla ilk etapta krize müdahale etmekten uzak bir görünüm sergilemiştir. Ancak BM ve AT’nin soruna karşı etkisiz, sınırlı, anlık çözümler üretmesi karşısında NATO çerçevesinde inisiyatifi eline alan ABD, yaptığı hava saldırılarıyla Sırp saldırılarını bastırmayı başarabilmiştir. Boşnaklara karşı Sırp milli- 
yetçiliğinin ve etnik temizliğin yoğun bir şekilde uygulanmaya çalışıldığ savaşta önceleri büyük kayıplar veren Boşnakların çatışmaların son anlarında ciddi bir taarruza başlamaları ve Sırp saldırıları karşısında önemli başarılar sağlaması sorunun barışla noktalanması için yapılan müzakerelerde Boşnakların lehine bir durum oluşturmuştur.

Yugoslavya'da bir iç çatışma olarak meydana gelen bu kriz, zaman ilerledikçe bölgesel bir tehdide dönüşmüş, Avrupa güçlerinin kriz karş1sındaki tepkisizliği çatışmanın boyutunu bölgesel olmaktan çıkarıp küresel bir niteliğe büründürmüştür. Böyle bir tablo karşısında bütün stratejik hamlelerini öne süren Batılılar, Rusya ve Çin gibi blokların da desteğiyle barış görüşmelerinin yapılması için adım atmaya karar vermişlerdir. Washington Anlaşması ve Temas Grubu çerçevesinde belirlenen \%51-49 oranının Dayton'da da kabul edilmesi, barışın tesis edilmesi için önemli bir aşama oluşturmuştur. Bu oransal toprak dağılımının ilk bölümü Boşnak-Hırvat Federasyonu'na verilirken, kalan topraklar da Sirplara devredilmiştir. NATO tarafından oluşturulan bir koruma gücünün bölgede görev yapması, mültecilerin geri dönüşü, Saraybosna'nın Boşnak-Hırvat Federasyonu'nun kontrolünde olması ve Brçko bölgesinin nihai statüsünün daha sonra belirlenmesi gibi koşulları içeren, 11 ek ve 102 haritadan oluşan Dayton Barış Anlaşması 21 Kasım 1995'te parafe edilmiş, 14 Aralık 1995 tarihinde ise imzalanmıştır. (Holbrooke, 1999: 336-337 ve Atabay, 2012: 275-277)

Üç etnik grubun da esasında imzalamak zorunda bırakıldığı bir anlaşma niteliğinde olan Dayton Anlaşması, bölgede anlaşmanın uygulanması aşamasında çıkan sorunlara zemin hazırlamıştır. Anlaşmanın imzalanmasında en etkili aktörlerden Holbrooke'un da açıklamaları 1şığında Dayton Anlaşması uygulanma aşamasında geliştirilmesi gereken bir anlaşma olarak tarihe geçmiştir. (Tekin, 2011: 29) Sırpların etnik temizlik ve soykırıma varan şiddetli saldırılarını meşrulaştıran anlaşma, Boşnakların da oluşturulan federasyon içerisinde Hirvatlarca dengelenmesine neden olmuştur. Sırpların bu girişimlerinin gereken biçimde kontrol altına alınamaması, bölgede barış ve istikrarın tesis edilmesini güçleştirmiştir. Nitekim anlaşma sonrası süreçte Mostar konusunda Boşnak-Hırvat anlaşmazlığı ve yine içinde Sırp faktörünün bulunduğu bir Kosova bunalımı yaşanmıştır. (Da- 


\section{$116 \cdot$ YALOVA SOSYAL BILIMLER DERGISI}

vutoğlu, 2009: 303-307)

Liderler ile ilgili detaylı bir araştırmaya gidilirken onların içinde bulundukları siyasi-sosyal koşulların göz ardı edilemeyeceği ilkesinden hareketle oluşturduğumuz bu bölümün akabinde şimdi de Aliya İzzetbegoviç'i bir siyasi lider ve düşünür olarak analiz etmeye çalışacağız.

\section{Aliya İzzetbegoviç’in Düşünce Dünyassına Genel Bir Bakış}

Aliya İzzetbegoviç’i incelemek, bir anlamda 20.yy dünya siyasi tarihinin dönüm noktalarını incelemek demektir; Aliya, Yugoslavya’nın üç tarihi dönemi olan I.Dünya Savaşı ve sonrası, II. Dünya Savaşı ve Soğuk Savaş dönemini tecrübe eden bir lider olmuştur. 1925 yılında Bosanski Samas'ta doğan lider, hayatının önemli bir bölümünü Saraybosna'da geçirmiştir. Burada 1938 yılında kurulan 'Genç Müslümanlar” teşkilatına katılan Aliya İzzetbegoviç, sonraki siyasi hayatına da yön verecek olan düşünsel altyapısını bu teşkilatta yaptığı okumalar ve tartışmalar sonrası edinmiştir. İslam dünyasının geri kalmışlığına çözüm için farklı bir perspektif sunan teşkilat, esasında dünyada bu yüzyılda gelişen İslami uyanışın bir örneğini teşkil etmesi açısından önemlidir. Aliya İzzetbegoviç'in siyasi hükümlü olmasına da sebep olan bu teşkilat, esasında onun düşünce hayatının şekillenmesinde etkili olmuş, ateizm, Marksizm üzerine düşünürün eleştirel bir takım değerlendirmeler yapmasına neden olmuş, nihayetinde onun kendini her anlamıyla ait hissettiği İslami kimliğine daha fazla sarılmasına yol açmıştır. Düşünürün hem ilk hapis hayatı hem de sonraki hapis hayatı, onun entelektüellik mücadelesinde motivatör görevi görmüştür. $\mathrm{Bu}$ yıllarda Aliya İzzetbegoviç Doğu ve Batı'nın kimliksel bunalımlarını iyi okumuş, Batı'nın açmazlarını Doğu'nun problem çözücü karakteriyle belirlemeye çalışmıştır. Batı'dan Kant, Hegel, Spengler gibi düşünürlerden etkilenirken Doğu'dan Seyyid Kutub, Fazlurrahman, Muhammed İkbal gibi aktivist-yazarlardan da bir takım gerçeklikler edinmeye çalışmıştır. (İzzetbegoviç, 2003: 38 ve Eliaçık, 2012: 13)

Kendini aklen Batılı, ruhen Doğulu olarak gören Aliya İzzetbegoviç, içinde bulunduğu ülkenin koşulları nedeniyle krallık, faşizm, komünizm ve demokrasi gibi farklı siyasal yapılanmaları da görme imkânı yakala- 
mıştır. Özellikle Soğuk Savaş döneminde ideolojik kamplaşmaların yoğun biçimde etkili olmasına karşın Aliya İzzetbegoviç, Müslümanların bu kamplaşmaya dâhil olmasına bir anlam verememiştir. Ona göre iki kutuplu dünya, Müslümanların temsil edilmediği bir dünyadır. Dolayısıyla Müslümanların yapması gereken üçüncü bir yol izlemeleridir. Bu genel görüşünü eserlerinde detaylı bir incelemeye tabi tutan Aliya özgürlük, adalet, evrim, kültür, ilerleme, tarih, medeniyet, ütopya gibi felsefenin ana gündem maddelerini oluşturan konular üzerine eğilmiştir. Onun bu çok yönlü okumalarının da etkisiyle sahip olduğu birikimi siyasi hayatıyla birebir yaşaması ve uyguladığı siyaset felsefesi, ayrıca düşünüre eleştirel, bütünlükçü, sorgulayıcı, rasyonel bir bakış açısı kazandırmıştır. Bu düşünce örgüsü çerçevesinde Aliya İzzetbegoviç ahlak, özgürlük, adalet gibi değerlerle Bosna Savaşı'ndaki mücadelesini başarıyla atlatıp düşüncelerini eylemleriyle birleştirebilmiş ender liderlerden olmuştur.

Aliya İzzetbegoviç, sahip olduğu tüm felsefi birikimi yazdığı eserleriyle bizlere aktarmayı başarmıştır. İslam Deklarasyonu-İslami Yeniden Doğuşun Sorunları, Özgürlüğe Kaçışım: Zindandan Notlar, Doğu Batı Arasında İslam, Tarihe Tanıklığım gibi eserler hem Aliya'nın felsefi birikimi hem de siyasi hayatının dönüm noktalarını içermesi bakımından önemlidir. Aliya bu eserlerde tanrı, aşk, varlık, hayat, ölüm, siyaset, din gibi insanlığın evrensel kaygılarıyla iç içe bir eleştiri eleği oluşturmaya çalışmıştır. Özellikle onun Doğu Batı Arasında Íslam adlı eseri, düşünce zenginliği açısından başyapıtıdır denilebilir. 60'lı yıllardan itibaren yazdığı bu eserde düşünür, Batı felsefesinin büyük çoğunluğuna etki eden Descartes'in düalist görüşünü ciddi bir biçimde sorgulamaya tabi tutmuştur. Düşünür, düalist felsefeyi Batı'nın temel açmazı olarak değerlendirmiş, onun varlığa dair ruh-beden şeklindeki ikilemini modern dünyaya da uyarlamaktan geri kalmamıştır. Burada Soğuk Savaş döneminde Doğu'yu komünizm ve materyalizmin temsil ettiği, Batı'nın da Hristiyanlık teolojisinden çokça etkilendiği görüşünü paylaşmıştır. Dolayısıyla iki kutuplu sistemin esasında materyalizm-idealizm, materyalizm-hristiyanlık ve materyalizm-ruhçuluk ikilemlerini sunmaya çalıştığı tespitini yapan Aliya İzzetbegoviç, uluslararası sistemin salt bu iki kutup üzerinden, bu ikilemlerle anlamlandırılmaya çalışılmasından yakınmıştır. Düşünür, 


\section{$118 \cdot$ YALOVA SOSYAL BILLIMLER DERGISI}

burada dünyanın salt iki ideoloji kalıbına uydurulmasındansa üçüncü bir yol izlemenin daha anlamlı ve gerekli olduğunu saptamıştır. (Latic, 2008: 61) Özetle bu eserinde Aliya İzzetbegoviç, tarihten bu yana bütün ideolojilerin, felsefi birikimlerin, düşünce yapılarının sadece üç ana kategori çerçevesinde değerlendirilebileceğini düşünmektedir; dini, materyalist ve İslami. Burada düşünür dini görüşün merkeze ruhu, materyalist görüşün ise maddeyi aldığını, İslami görüşün de bu iki bağımsız ve zıt kutbu yakınlaştırmaya, birleştirmeye, ikisini bir arada ele almaya çalıştığını ifade etmiştir. Bu değerlendirmeyi İslam'ın “vasat” özelliğiyle temellendirmeye çalışan düşünür, bu tespitine Kuran' dan da karşılıklar vermekten geri kalmamıştır. (Aliya, 2012: 11)

$\mathrm{Bu}$ eserinden mülhemle, özgürlük ve ahlakın Aliya İzzetbegoviç’in en fazla önemsediği değerler olduğunu söylemek mümkündür. Düşünüre göre bir insanı var ve değerli kılan, onun özgür olabilmesidir. O, insanın ancak özgür oluşuyla değerli olduğunu savunmuştur. Buradan hareketle düşünür, özgürlük ve ahlakın insanın iç yapısı ile alakalı olduğunu yani “ "öz"den geldiğini iddia etmiş, dolayısıyla bu iki değerin bu nitelikleri sayesinde insana hiçbir şekilde dişsal bir müdahaleyle yön verilemeyeceğini savunmuştur. Buna ek olarak iyilik ve kötülüğün de bu şekilde değerlendirilebileceğini düşünmüştür. Baskı, zor, şiddet yoluyla insanın sadece davranışlarının şekillendirilebileceğini, ruha müdahale etmenin mümkün olmadığını kaydeden Aliya İzzetbegoviç, bu yöntemlerin ahlakın ıslah edilmesi için işlevsel olamayacağını savunmuştur. Ayrıca düşünüre göre ahlak rasyonel olamaz, ahlaki açıdan tarafsız kalınamaz ve aynı zamanda ahlak işlevsel de olamaz. Ahlak mefhumunu bu kriterlerle belirlemeye çalışan düşünür, onun din olmadan var olamayacağını da savunmuştur. Tarih, ona göre ahlak-din birlikteliğinin örnekleriyle doludur ve ikisi arasında karşılıklı bir bağımlılık mevcuttur. Ayrıca ahlak burada yasaklardan oluşuyla dini özelliğini korumayı sürdürmektedir. Allah'ın ilettiği ilk on emrin sekizinin yasaklardan oluşunu Aliya İzzetbegoviç bu tespitlerine kanıt olarak sunmuştur. (Aliya, 2012: 176-181)

Aliya İzzetbegoviç hapis hayatı, savaş yılları, siyasi hayatı ve düşünsel birikimiyle bizim açımızdan ne sıradan bir lider, ne tarafsız bir komutan, ne de kayıtsız bir siyaset adamıdır. Ayrıca o uluslararası toplumun 
sorunlarına duyarsız, tepkisiz kalan biri de değildir. Devlet başkanlığı, ordu komutanlığ 1 , parti başkanlığ 1 ve entelektüel rolleri sayesinde Aliya İzzetbegoviç, 20. yy.' da bir liderin düşündüklerini nasıl tutarlı bir biçimde yaşatmayı başarabildiğini göstermesi açısından çok anlamlı bir rol oynamıştır. Eserlerindeki değerleri kuru bir bilgi olarak sunmayıp onları siyaset hamlelerine yansıtması, düşünürün bir bağımsızlık mücadelesinde ne derece etkili olduğunu görmemiz açısından da ayrı bir öneme sahiptir.

\section{Realizm-İdealizm Tartışmasına Farklı Bir Açılım: Aliya İzzetbegoviç'in Siyaset Felsefesi}

Çalışmamızın bu bölümünde klasik anlamda idealizm-realizm tartışmasına yer vermek yerine, iki disiplinin ön kabullerini tespit ettikten sonra Aliya İzzetbegoviç'in siyaset felsefesine uyarladığı şekliyle bu teorilere alternatif olarak sunduğu modeli incelemeye çalışacağız. Burada Doğu Batı Arasında İslam adlı eserinde Aliya İzzetbegoviç'in belirlediği din-materyalizm, dram-ütopya, tekâmül-yaratma gibi ikilemler bu başl1ğın değerlendirilmesi için önemli tartışmaları içermektedir.

Özellikle I. Dünya Savaşı yıllarına doğru gerginleşen uluslararası ortamın La Haye konferansları ile sağlanmaya çalışılan barış ve güvenlik durumunun tartışılması uluslararası ilişkiler teorileri açısından idealizmin doğuşu olarak ifade edilebilir. Ancak bu teorinin meşruiyetini sağlaması realizm sayesinde olmuştur denilebilir. Savaş sonrası istikrar ortamının tesis edilmesi adına kurulan Milletler Cemiyeti'nin de teoriye aktör bazında katkı sunması, idealizme yönelik görüşlerin olumlu olmasıyla neticelenmiştir. Ancak Almanya ve İtalya gibi ülkelerin yayılmacı politikaları nedeniyle II. Dünya Savaşı'na gidilmesi idealizmin dayanak noktalarını ortadan kaldırmıştır. Tarihe 'kurucu tartışma" olarak geçen realizm-idealizm tartışmasının esas kaynağı bilhassa bu olay olmuştur. (Çalış; Özlük: 225 ve Sönmezoğlu vd, 2013: 46)

İdealizmin temelleri aslında Kant, Rousseau ve Grotius'a kadar götürülebilir. Teorinin ana iddiaları arasında öncelikli olan şey, insan doğasının "'iyimser" olarak değerlendirilmesidir. Dolayısıyla bu teoride devletler ve uluslararası sistem de tıpkı insanlar arasında olduğu gibi barış ve istikrar 


\section{$120 \cdot$ YALOVA SOSYAL BILLIMLER DERGISI}

ortamına dönüşebilir. Uluslararası kurumların varlığı, demokratik yapılanmaların teşvik edilmesi, ticaretin ülkesel sınırları aşması ve ahlaki değerlerin ön plana alınması gibi ilkeler, idealist teorinin ana iddiaları arasında yer almıştır. (Eralp, 1996: 62)

İşbirliği, barış, istikrar gibi kavramların yoğun karşılık bulduğu idealizm, realistlerin insan doğasına yaklaşımına sert bir biçimde karşılık vermiştir. Klasik realizm burada, idealizmin aksine, insanı doğuşu itibarıyla "kötü, ve günahkâr" olarak görerek, insanlar ve devletler arasındaki ilişkiyi de "kötümser" olarak değerlendirir. Dolayısıyla realistlere göre devletler kuşku ve güvensizlik içerisinde sürekli bir güç yarış1 içindedirler. Askeri ve siyasi konuların ön planda olduğu klasik realizmin temeli esasında Sun Tzu, Thucydides gibi düşünürlere dayandırılsa da, teorinin isim babası Makyavel olmuştur denilebilir. İnsanlar ve devletlerarası ilişkilerin güç ve çıkar ilişkisine indirgendiği bu Makyavelist teori, klasik anlamda ittifaklara dayalı güç dengesinin korunması yönündeki telkinleri sayesinde günümüze kadar etkisini korumuştur. (Ar1, 2008: 172-173) Halâ modern devletlerin diş politik hamlelerine etkide bulunan realist teori, son zamanlarda eleştirel bir takım kuramlarca baskıya maruz kalsa da 21. yy.'da devletlerarası politikalarda iddiasını sürdürmektedir.

Realizm-idealizm tartışmasında Aliya İzzetbegoviç'in bulunduğu yer aslında tartışmanın gündemine dairdir. İki teoriye de eleştirel yaklaşan Aliya İzzetbegoviç, her şeyden önce insana dair bakışını şöyle açıklamıştır:

' 'Tanrı'nın insanları özgür ve eşit olarak yarattığına, herhangi bir ırk diğerinden üstün olmadığı gibi, herhangi bir milletin de diğerinden iyi veya kötü olmadığına inanıyorum. İnsanın devredilemez haklarla doğduğuna, herhangi bir otoritenin insanları bu haklardan mahrum birakma hakkının olmadığına inanıyorum. Çoğunluğun sınırsız gücüne ise inanmıyorum, çünkü çoğunluk despotizminin başka despotizmlerden farkı yoktur. Özgürlüğün ölçüsü azınlıklara nasıl davranıldığıdır ve insanların farkl1 düşünebilme özgürlüğünden önce düşünce özgürlüğüne sahip olmas1 gerekir. İşte benim demokrasi anlayışımın özeti budur.” (Aliya, 2003: 378)

İdealistlerin insana bakışıyla benzerlik gösteren bu bakış açısı ' Doğu

YIL: 6 SAYI: 11 
Batı Arasında İslam” adlı eserinde “'ideal toplum” başlı̆̆ı altında detaylı bir şekilde yer almıştır. Burada Aliya İzzetbegoviç insan üzerine "'iyi ve kötü’ değerlendirmesi yaptıktan sonra realizmin insana yönelik kötümser duruşuna karşı çıkmış; ancak Platonist idealizmi de reddetmiştir. Adeta iki teori arasında bir denge oluşturmaya çalışan İzzetbegoviç burada ne katı bir realist, ne de kör bir idealist olmuştur. Bunun yanı sıra Aliya İzzetbegoviç, Hobbes'un insanlar arasındaki duygusal yakınlaşmayı güvenlik endişesine bağlaması yönündeki görüşünü de şiddetle eleştirmiştir. Düşünüre göre, insanlar pragmatist olmayan eğilimleriyle de topluluk oluşturabilirler ve burada değerli olan esasında böyle bir davranıştır. (Aliya, 2012: 219-232) Özetle Aliya İzzetbegoviç uluslararası kurumların işlevselliği, insana karşı bakışı, moral değerlere bağlılık, demokratik yapılanmaların tercih edilmesi gibi iddialarla idealizme yakın bir felsefi birikim edinmiştir. Ancak, Bosna Savaşı'nda da yaşandığı gibi uluslararası sistemde halâ realizmin etkilerinin çokça görülmesi düşünürü hayal kırıklığına uğratmıştır. Dolayısıyla düşünür Makyavelist teoriye, moral değerlere önem vermemesi açısından bir karşıt duruş sergilemiştir.

Aliya İzzetbegoviç'in bu felsefi birikimi sayesinde yürüttüğü siyaset felsefesine değinilecek olursa, öncelikle onun kendine has bir siyaset yürütmeye çalıştığını söylemek mümkündür. Düşünürün siyaset algısı, moral değerler ile siyasetin bir arada olması gerektiğini savunan Kantiyen Yaklaşım'a benzerdir. (Cevizci, 2009: 744) Tıpkı Kant gibi Aliya'da da siyaset ve ahlak felsefesinin bir arada yürütüldügü; ancak ahlakın ön planda olduğu bir siyaset algısı mevcuttur ve düşünürün siyaset felsefesinin merkezinde insan yer almaktadır. İnsanlar için daha iyi bir barış ortamı sunma amaçlı yürütülen siyaset anlamını Aliya İzzetbegoviç'de çokça bulmuştur; zira Aliya İzzetbegoviç insani olan evrensel değerleri bir bir siyaset felsefesine uyarlamaya çalışmıştır. İnsanın bu yapısına karşıt olan her türlü yapılanmayı totaliter olarak gören düşünür, otorite ve totalitarizmin birbiriyle ters orantılı olduğunu savunmuştur. Yani düşünürün siyaset felsefesinde baskı arttıkça otorite zayıflamaya mahkûm olur. Dolayısıyla düşünür, totaliter sistemlerin istikrarı sağlayamayacağı görüşündedir. Ona göre gerçek bir iktidar, insana özgürlüğünü yaşama imkânı veren iktidardır. Siyasette menfaat yerine sorumluluk prensibiyle hareket eden Aliya İzzetbegoviç, dış politik adımlarının tümünü vazife üzerinden yürütmüş- 


\section{2 • YALOVA SOSYAL BILLIMLER DERGISİ}

tür. Sorumluluğu ahlak ile ölçmeye çalışan düşünür, ahlak temelli siyasetini bu alg1 üzerine bina etmiştir. (Karaarslan, 2010: 69-70)

Aliya İzzetbegoviç'in siyaset modelinde ulus-devletler de tartışma konusu olmuştur. Düşünüre göre artık ulus-devletler günümüz uluslararası ilişkiler dünyasında yeterli olamamaktadır. Böyle fraksiyonlarda demokrasinin de işlevsel olamayacağını düşünen Aliya İzzetbegoviç'in model olarak sunduğu siyasi yapılanma demokratik bir cumhuriyettir. Buradan hareketle demokrasi kavramına değinen düşünür, demokrasinin belki de tarihte en az din kadar yanlış anlaşıldığını, her siyasal sistemin kendini demokratik olarak gördüğünü paylaşmıştır. Dolayısıyla despotların demokrasi vurgusuyla halk yığgnlarını ikna etmeye çalıştığını öne süren İzzetbegoviç'e göre bir sistemin demokratik olup olmaması sistem içerisindeki azınlıklara nasıl bakıldığıyla ölçülebilir. Düşünür burada demokrasi kavramına 'kanunların denetimi ile sağlanmış halk iradesi" şeklinde bir açılım yapar. (Aliya, 2003: 378) Siyaset modelinde yer verdiği demokratik sistemde kadınların önemini de vurgulayan Aliya İzzetbegoviç'in siyasi hayatında yazdıklarıyla yaşadıklarının tutarlılık göstermesi, günümüz modern devlet yapılanmaları için önemli bir model oluşturabilecek niteliktedir. Dolayısıyla onun kurguladığı siyaset felsefesinin tümüyle değerlendirilmesi, uluslararası ilişkiler disiplininin uluslararası barış kaygısı adına incelenmeye değerdir.

\section{Aliya İzzetbegoviç’in İslam Perspektifi}

Aliya İzzetbegoviç'in siyasi hayatı incelenirken, onun düşünce ve eylemlerini derinden etkileyen İslami duyarlılığını ele almamak, sığ bir araştırma yapmak demektir. Dolayısıyla bu başlık, Aliya İzzetbegoviç'in genel anlamda İslam'a dair düşüncelerini içermektedir.

Aliya İzzetbegoviç’in yaşadığı dönem, hem uluslararası sistem açısından ciddi dönüşümlerin yaşandığı, hem de İslami anlamda yeni birtakım görüşlerin ileri sürüldüğü bir dönem olmuştur. Özellikle Ortadoğu kaynaklı bu yeniden bilinçlenme hareketi, Arap milliyetçiliğiyle karışık modernist bir eğilime sahip olmuştur. Ancak düşünsel açıdan İ́slam coğrafyasında böylesi farklı gelişmelerin yaşanması, İslam toplumlarına umut kaynağı olmuştur. Böyle bir ortamda 'Müslüman Kardeşler', ' Cemaat-i 
İslami" gibi İslami anlamda bir takım teşkilatlanmalar bölgesel kaynaklı oluşumlar olarak doğsa da zamanla küresel çapta katılımcıyla dünya siyasetinde söz sahibi olmaya çalışmışlardır. Bu dönemde Aliya İzzetbegoviç'in de dâhil olduğu 'Genç Müslümanlar" örgütü de Yugoslavya içerisindeki Müslümanların kimliklerini koruma çabalarında onlara ciddi destek sağlamıştır. $\mathrm{Bu}$ yıllar içerisinde Batı emperyalizmine tepki olarak da gelişen İslami uyanış hareketlerine Cemaleddin Afgani, Reşit Rıza, Muhammed Abduh gibi düşünürler öncülük etmiş, bu düşünürleri Muhammed İkbal, Malik Bin Nebi, Fazlurrahman, Seyyid Kutub, Ali Şeriati, Mevdudi, Hasan El Benna gibi aktivasyon sahibi karakterler izlemiştir. (Lapidus, 2002: 580-585) Laiklik, batılılaşma, sömürgecilik gibi politikalara karşı düşünsel ve eylemsel muhalefet sergileyen bu düşünürler arasında ses getiren ve liderlik rolü de olan Aliya İzzetbegoviç de yer almıştır.

Aliya İzzetbegoviç'in İslam algısı, onun Hristiyanlık ve Yahudilik inançlarından farklı oluşuyla temellenmiştir. Düşünür, insan ile ilgili değerlendirmeler açısından bu üç dinin farklılıklar taşıdığını saptamış ve insanı ontolojik bir gerçeklik olarak doğru değerlendiren tek inancın İslam inancı olduğu sonucuna varmıştır. Özellikle Hristiyanlık teolojisinin Hz. İsa örneğinde olduğu gibi insanı kutsayıcı yaklaşımına karşı çıkan Aliya İzzetbegoviç, Yahudilik öğretisinde "seçilmiş topluluk" olgusunun da yanlış olduğu kanısına varmıştır. (Aliya, 2006: 172) Bu inançlar arasında monoteist yapısını koruyan tek inancın İslam olduğunu vurgulayan düşünür, diğer öğretilerin insan hürriyetine iç ve dış anlamda sınırlamalar getiren yaklaşımına da karşı çıkmış, İslam'ın insanın hem iç hem de dış hürriyetini birlikte sağlayan bir inanç olduğunu tespit etmiştir. Özetle İslam, düşünüre göre ibadet yerlerinin işlevselliği, ruhban sınıfı, siyasete ve insana bakışı, zulme karşı kuvvet kullanma gibi toplumun hayati önemde ilişkileri açısından diğer inançlara göre farklılık taşımaktadır. (Aliya, 2006: 258-263)

Aliya İzzetbegoviç, İslam ile ilgili değerlendirmelerinde her şeyden önce İslam tarihini Hz. Muhammed öncesi ve sonrası şeklinde iki dönemde incelemektedir. Hz. Muhammed öncesi dönem Hristiyanlık ve Yahudilik öğretilerinin bir kısmını da içerirken, düşünüre göre asıl İslam tarihi Hz. Muhammed sonrası dönemi teşkil eder. (Aliya, 2012: 249) 


\section{4 • YALOVA SOSYAL BILIMLER DERGISI}

Bu değerlendirmeden sonra düşünür, geleneksel anlamda yüzyıllardır kabul edilen İslam'ın beş şartının İslam'ın ana mesajı olduğu görüşüne karşı çıkmış, ona göre İslam'ın ana mesajı 'iman edin ve salih amel işleyin ” gibi toplumu dönüştürebilen bir mesaj olmalıdır. İslam'ın beş şartının ancak bu dönüşüm sağlandıktan sonra çok daha etkili olabileceğini düşünen Aliya İzzetbegoviç, toplumların yüzyıllardır bu beş şartı taşımakla kendini Müslüman kabul edip bir nevi rahat bir hayatı seçtiğini dolay1sıyla İslam coğrafyasında yaşanan her şeyin İslam olarak görülmesi gibi yanlış bir algının ortaya çıktığını tespit etmiştir. Bu durumda düşünüre göre İslam'ın asıl mücadeleci ruhunu temsil eden ana mesaj ' 'iman edin ve salih amel işleyin" mesajıdır. Eserlerinde de ortaya koyduğu üzere İslam'ın temel parolasını 'Allah 'tan başka ilah yoktur" şeklinde vurgulayan düşünür, hedef olarak da 'Müslüman halkların İslamlaşması" şiarını benimsemiştir. (Aliya, 2014: 101-161)

Aliya İzzetbegoviç, son peygamberin Mekke yıllarını İslam olarak değerlendirmek yerine, onun siyasi-toplumsal müesseseleşme süreci olan Medine sürecini İslam olarak değerlendirmiştir. Peygamberin Hira'dan ayrılmasını, onun haniflikten sıyrılması olarak gören düşünür, bu ayrılık neticesinde onun İslam'ın son peygamberi olduğunu savunmuş, bu süreci de mistik ile aklın, meditasyon ile eylemin karşılaşması şeklinde aktivasyon içerikli bir dönüşüm şeklinde açıklamıştır. (Aliya, 2012: 257)

Namaz, oruç, zekât, hac gibi temel kavramlarla ilgili ezber bozucu nitelikte açılımlar yapan Aliya İzzetbegoviç, İslam coğrafyasında yaşanan kanlı çatışmaları da İslam temelli bir takım eleştirilerle yorumlamaya çalışmıştır. İslam ülkelerinin Batı karşısında neden ayakta duramadığ sorusuna önemli bir yer ayıran düşünür, bu sorunun temelinde İslam ve Kuran'ın tabiata bakış açısının göz ardı edildiğini, dolayısıyla bunun Batı karşısında teknolojik bağımlılığın beraberinde siyasi bir bağımlılık da oluşturduğunu savunmuştur. (Aliya, 2012: 199-202) Ayrıca İslam'ın salt bir teolojik olgu olarak değerlendirilmesi sonucu yaşanan geri kalmışl1ğa çözüm olarak Aliya İzzetbegoviç, eğitim ve İslam'da gözlem gücünün tekrar kazanılmasını sunmuştur. İslam'ın Batı'daki algıyla salt bir ' din" olarak telakki edilmesine karşı çıkan Aliya İzzetbegoviç, bu görüşün İslam'ın mücadeleye dönük siyasi taleplerinin kaybolmasına neden olduğu

YIL: 6 SAYI: 11 
değerlendirmesini yapmıştır. (Aliya, 2012: 263) Bu açıklamalar çerçevesinde düşünür İslam'ın yeniden doğuş hedefini 'Íslam 'in bireysel, ailevi ve toplumsal hayatımızın tüm alanlarında İslam düsüncesinin yenilenmesi ve Endonezya'dan Fas'a kadar tek bir İslam birliğini gerçekleştirmek." olarak benimsemiştir. (Aliya, 2010: 19-20)

Aliya İzzetbegoviç, sadece sorunları ortaya dökmek gibi sığ bir tartışma yaratmak yerine, sorun olarak gördüğü olgulara karşı çözüm önerileri de sunmayı bir gereklilik olarak görmüştür. $\mathrm{Bu}$ anlamda düşünür yaşanan sorunlara çözüm olarak eserlerinde eşitlik, adalet, insan-toplum ilişkisi, Müslümanların kardeşlik ve birliği, özel mülkiyet, zekât ve faiz, eğitim, öğretim, tevhid çağrısı, bağımsızlık, çalışma ve mücadele, kadın ve aile gibi temel konular üzerinden bir "İ́slami Rönesans" söylemi geliştirmiştir. Son olarak bilhassa Ortadoğu ülkelerinin içinde bulunduğu siyasi-toplumsal istikrarsızlıkların ancak Batılıların oluşturduğu "Avrupa Birliği" gibi bir modelle giderilebileceğini düşünen Aliya İzzetbegoviç, İslam ülkelerinin federal, süpranasyonel bir takım oluşumlara muhtaç olduğunu gözlemlemiştir. (Aliya, 2010: 81-88) Dolayısıyla siyasi hayatı boyunca gittiği her ülkede böyle bir birlikteliğin gerekli olduğunu dile getirmiş, bunu sağlamak adına da öncelikle kendi ülkesiyle Ortadoğu ülkelerinin yakın ilişkiler ağı kurmasına öncülük etmeye çalışmıştır. Müslüman hakların bu şekilde bir birlik oluşturarak Batı'ya karşı ayakta durabileceğini düşünen Aliya İzzetbegoviç, İslam'ın yitik talebi olan siyaseti tekrar İslam içerisine dâhil etmeye çalışmıştır. Onun farklılık yaratan yüzünün bir bölümü, böyle bir bakışla görülmelidir.

\section{Sonuç}

Aliya İzzetbegoviç'in siyasi ve entelektüel hayatıyla uluslararası ilişkiler disiplinine yaptı̆̆ katkıları incelemeye çalıştığımız bu araştırmada sonuç olarak öncelikle Aliya İzzetbegoviç ve Bosna-Hersek'in ayrı, bağımsız birer olgu olarak ele alınamayacağını söylemek yerinde olur. Özellikle ülkesinin bağımsızlık mücadelesinde entelektüel ve siyasi rolleriyle bu mücadeleyi olumlu yönde etkileyen temel motivatör olarak kabul edilebilen Aliya İzzetbegoviç’in bizler için en önemli yanı, Soğuk Savaş 


\section{$126 \cdot$ YALOVA SOSYAL BILIMLER DERGISI}

döneminde uyguladığı rasyonel siyasetle uluslararası ilişkiler dünyasına siyaset felsefesi anlamında yeni bir hava katmış olmasıdır.

İki kutuplu sistemin çözüldüğü yıllarda ülkesinde bağımsızlık mücadelesi veren Aliya İzzetbegoviç, Batı'nın reel politiğine Doğu'lu bir ruhla karşılık vermeye çalışmıştır. Bu mücadele sürecinde Doğu'lu kimliğine sımsıkı sarılan düşünür, sahip olduğu bu birikimi Batı'nın açmazlarına karşı bir koz olarak öne sürmüştür. Batı'nın felsefi birikimini özümseyen düşünür, insani endişelerini Doğu'lu kimliğiyle evrensel bir tepki olarak Batı'ya karşı bir mücadele sahası olarak öne sürmüş̧ür. Siyasette ahlak, adalet, eşitlik gibi Batı'nın göz ardı ettiği moral değerlerin siyasette uygulanabilirliğini kanıtlayan bir düşünür olarak Aliya İzzetbegoviç'in entelektüel dünyasını perdelemek, belki de Yeni Dünya Düzeni veya düzensizliğinin konuşulduğu yılları anlamak açısından çok gerekli bir katkı sağlayacaktır. Bunun yanı sıra Aliya İzzetbegoviç’in reel politiğe taviz vermeyip aynı zamanda idealizmin etkisiz yanlarından sıyrılması da uluslararası ilişkiler disiplini için yeni bir tartışma konusu olabilecek niteliktedir. Bu bağlamda uluslararası ilişkiler teorilerinde idealizm-realizm arasında bir dünya düşünmenin boyutlarını incelemek açısından düşünürün ortaya koyduğu siyaset bir model olarak ele alınmalıdır. Siyaset-ahlak birlikteliğinin post-modern dönemde de mümkün olabileceğini bizlere kanıtlayan düşünür aynı zamanda Bosna-Hersek krizinde miras olarak model niteliğinde sunulabilecek bir savaş hukuku da bırakmıştır. Ahlaki değerlerin bir ölçüt olarak alınmadığı günümüz krizlerinde Aliya İzzetbegoviç'in düşmana karşı intikam duygularını törpüleyen engelleme girişimleri, savaş hukukunda insani kaygıların dikkate alınması açısından ayrı bir öneme sahiptir.

Çalışmamızda önemsediğimiz bir diğer konu da Aliya İzzetbegoviç'in İslam algısıdır. İslam düşünce dünyasına farklı bir heyecan katan, bu bağlamda İslam düşüncesini yeni bir açılıma tabi tutan düşünür, 'IIslami Rönesans" teziyle düşünsel olandan eylemsel olana doğru ortaya yeni bir iddia koymuştur. Bu karakteriyle 20. yy. İslam düşünürleri arasında yer edinen Aliya İzzetbegoviç'in İslam algısında İslam'a yeniden doğuş, esasında İslam'a yeniden dönüş olarak görülmelidir. İslam coğrafyasının içinde bulunduğu siyasi, sosyo-ekonomik istikrarsızlıkların tümünü İslam 
ve Kuran'dan uzaklaşmak şeklinde belirleyen düşünür, hedef olarak geleneksel kalıpların dışına çıkan ve İslam'ın ana referanslarına dönüş yapan bir bakış açısı sunmuştur. Temel problemi İslam'dan uzaklaşmak olarak belirleyen düşünürün eserlerinde yoğun olarak yararlandığı düalist felsefenin de İslam felsefesi çalışmalarına ayrı bir bakış açısı kattığ 1 ortadadır. $\mathrm{Bu}$ anlamda Batı'nın düalist felsefesinin de farklı bir yoruma tabi tutulması, akademik çalışmalar için ayrı bir motivasyon kaynağı olabilecek niteliktedir.

Özetle, Aliya İzzetbegoviç üzerine yapılacak akademik bir çalışma uluslararası ilişkiler disiplininin inceleme alanı olan uluslararası ilişkiler teorilerine, uluslararası politikaya ve uluslararası hukuka katkı sunacaktır. Ayrıca buna ek olarak düşünürün taşıdığı İslami kimlik, İslam'a ve İslam coğrafyasına farklı bir açıdan bakabilmeyi sağlayacaktır. Bu açıdan Aliya İzzetbegoviç'in çok yönlü karakter yansımaları, uluslar arası ilişkilerin disiplinlerarası yapısıyla örtüşmektedir. Bu çalışmanın niteliği akademik dünyaya yaptığı bu katkılar ile değerlendirilebilir.

\section{KAYNAKÇA}

ALKAN, Necmettin; (2013), ), 'Yugoslavya'nın Dağılması”, Editörler: GÖKDAĞ, B. A., ve O. Karatay, Balkanlar El Kitabı 2: Çă̆daş Balkanlar, 2. Baskı, Akçă̆ Yayınları, Ankara, s. 33-55.

ARI, Tayyar (2008), Uluslararası Illişkiler Teorileri: Çatışma, Hegemonya, İşbirliği, 5. Bask1, MKM Yayınc1lı,, Bursa.

ARMAOĞLU, Fahir (2012), 20. yy. Siyasi Tarihi: 1914-1995, 18. Bask1, Alkım Yayınevi, İstanbul.

ATABAY, Mithat (2012), 20. yy'da Türkiye ve Balkanlar: Savaş, Barış, Göç ve Dramın Tarihi, 1. Bask1, Kriter Yayınevi, İstanbul.

BERGHORN, Detlef; (2013), 'Yugoslavya ve Dağılan Yugoslavya'dan Doğan Devletler”, Çev., Aysun Yavuz, Editör: Derya Tulga, Dünya Tarihi, 5. Bask1, NTV Yayınları, İstanbul, s.416-469.

CEVIZCİ, Ahmet (2009), Felsefe Tarihi: Thales 'ten Baudrillard'a, 1. Bask1, Say Yayınları, İstanbul 


\section{$128 \cdot$ YALOVA SOSYAL BILIMLER DERGISI}

ÇALIŞ, Şaban ve E. Özlük, ‘'Uluslararası İlişkiler Tarihinin Yapısökümü: İdealizm-Realizm Tartışması", s. 225-236, http://www.nuveforum.net/717-uluslararasi-iliskiler-bolumu/100890-uluslararasi-iliskiler-tarihinin-yapisokumu-idealizim-realizm-tartismasi/ 10.11 .2014 .

DAVUTOĞLU, Ahmet (2009), Stratejik Derinlik: Türkiye'nin Uluslararası Konuтu, 36. Baskı, Küre Yayınları, İstanbul.

ELİAÇIK, R. İhsan (2012), Çağa İz Bırakan Önderler: Aliya İzzetbegoviç, 4. Baskı, İlke Yayıncılık, İstanbul.

ERALP, Atila (1996), 'Uluslararası İlişkiler Disiplininin Oluşumu: İdealizm-Realizm Tartışması", Editör: Atila Eralp, Devlet, Sistem ve Kimlik: Uluslararası İlişkilerde Temel Yaklaşımlar, İletişim Yayınları, İstanbul, s. 57-88.

ERDOĞAN, Koray (2004), 'Yugoslavya'nın Dağılma Sürecinde ABD ve Bosna-Hersek Krizi”, Kocaeli Üniversitesi, Sosyal Bilimler Enstitüsü, Yüksek Lisans Tezi, Kocaeli..

HOLBROOKE, Richard; (1999), Bir Savaşı Bitirmek, Çev., Belkıs Çorakçı Dilbudak, 1. Baskı, Türkiye İş Bankası Kültür Yayınları, İstanbul.

IZZETBEGOVİÇ, Aliya; (2003), Kendi Kaleminden Aliya İzzetbegoviç: II. Endülüs Soykırımına Geçit Vermeyen Bilge Adam, Çev., Alev Erkilet, A. Demirhan, H. Öz, Dergah Ofset (Vakit Gazetesi) Yayınları.

İZETBEGOVİÇ, Aliya; (2006), Özgürlüğe Kaçışım: Zindandan Notlar, Çev., Hasan Tuncay Başoğlu, 4. Baskı, Klasik Yayınları, İstanbul.

İZZETBEGOVİÇ, Aliya; (2010), İslam Deklarasyonu, Çev., Rahman Ademi, 4. Bask1, Fide Yayınları, İstanbul.

İZZETBEGOVIÇ, Aliya; (2012), Doğu Batı Arasında İslam, Çev., Salih Şaban, 4. Bask1, Yarın Yayınları, İstanbul.

İZZETBEGOVİÇ, Aliya; (2014), İslami Yeniden Doğuşun Sorunları, Çev., Rahman Ademi, 1. Baskı, Fide Yayınları, İstanbul.

JUDT, Tony; (2009), Savaş Sonrası: 1945 Sonrası Avrupa Tarihi, Çev., Dilek Şendil, 1. Bask1, Yapı Kredi Yayınları, İstanbul.

KARAARSLAN, Faruk (2010), ' Entelektüel Üzerine Eleştirel Bir Çalışma: Aliya İzzetbegoviç Örneği”, Selçuk Üniversitesi, Sosyal Bilimler Enstitüsü, Yüksek Lisans Tezi, Konya. 
SOĞUK SAVAŞ SONRASI BOSNA-HERSEK BAĞIMSIZLIK SÜRECI VE ALIYA İZETBEGOVIÇ• 129

KENAR, Nesrin; (2013), “'Bosna-Hersek Savaşı”, Editörler: GÖKDAĞ, B. A., ve O. Karatay, Balkanlar El Kitabı 2: Çağdaş Balkanlar, 2. Bask1, Akçağ Yayınlar1, Ankara, s.181-205.

LAPIDUS, Ira M. (2002), A History of Islamic Societies, Second Edition, Cambridge University Press.

LATIC, Cemalettin; (2008), 'Batı'daki İkbal”, Bağcılar Belediyesi Uluslararası Aliya İzzetbegoviç Sempozyumu, Editörler: Ömer Hakan Özalp ve K. Gültürk, Kültür Yayınları, İstanbul, s. 61-71.

ROBERTS, J. M.; (2013), Dünya Tarihi: 18.yy ve Sonrası (2. Cilt), Çev., İdem Erman, T. Akgün, İnk1lap Yayınları, İstanbul

SANDER, Oral (2004), Siyasi Tarih: 1918-1994, 12. Bask1, İmge Kitabevi Yayınları, Ankara.

SÖNMEZOĞLU, F., H. Güneş, E. Keleşoğlu (2013), Uluslararası İlişkilere Giriş, 1. Baskı, Der Yayınları, İstanbul.

TEKİN, Cemile (2011), '’Bosna-Hersek Kaynaklarına Göre Yugoslavya'nın Dağılmasından Sonra Bosna Hersek Federasyonu'nun Kurulması”, Selçuk Üniversitesi, Sosyal Bilimler Enstitüsü, Doktora Tezi, Konya. 